\title{
Beyond deforestation monitoring in conservation hotspots: analysing landscape mosaic dynamics in north-eastern Madagascar
}

\begin{abstract}
Due to its extraordinary biodiversity and rapid deforestation, north-eastern Madagascar is a conservation hotspot of global importance. Reducing shifting cultivation is a high priority for policy-makers and conservationists; however, spatially explicit evidence of shifting cultivation is lacking due to the difficulty of mapping it with common remote sensing methods. To overcome this challenge, we adopted a landscape mosaic approach to assess the changes between natural forests, shifting cultivation and permanent cultivation systems at the regional level from 1995 to 2011 . Our study confirmed that shifting cultivation is still being used to produce subsistence rice throughout the region, but there is a trend of intensification away from shifting cultivation towards permanent rice production, especially near protected areas. While large continuous forest exists today only in the core zones of protected areas, the agricultural matrix is still dominated by a dense cover of tree crops and smaller forest fragments. We believe that this evidence makes a crucial contribution to the development of interventions to prevent further conversion of forest to agricultural land while improving local land users' well-being.
\end{abstract}

Keywords: shifting cultivation; land use change; protected areas; agricultural intensification; Makira Natural Park; Masoala National Park 


\section{Introduction}

Tropical forest landscapes have been modified by humans for tens of thousands of years with increasing intensity (Malhi, Gardner, Goldsmith, Silman, \& Zelazowski, 2014). The expansion of agricultural land is a main driver of forest conversion (Gibbs et al., 2010), ranging from large-scale agribusinesses to smallholder subsistence farms (Laurance, Sayer, and Cassman, 2014). In many countries the concern has now shifted to large-scale forest clearance linked to the engagement in international agricultural markets and the growth of urban populations (DeFries, Rudel, Uriarte, \& Hansen, 2010; Lambin \& Meyfroidt, 2011; van Vliet et al., 2012). Madagascar seems to be an important exception to this trend, with the retraction of its humid forest frontier still due to smallholders' expansion of agricultural land to produce subsistence rice through shifting cultivation (van Vliet et al., 2012). In Madagascar, as in other shifting-cultivation hotspots around the globe (Ickowitz, 2006; Mertz et al., 2009), shifting cultivation has since colonial times been considered irrational and unsustainable, leading to the destruction of biodiversity-rich forests (e.g., Humbert, 1927 in Kull, 2000).

Land change science offers a strong conceptual framework to analyse transitions in land use systems dominated by smallholders (Turner, Lambin, \& Reenberg, 2007). Adopting a sustainability perspective, it seeks to understand the dynamics of land cover and land use as a coupled human-environment system (Global Land Project, 2005; Reenberg, 2009). The resulting knowledge should help policy-makers to steer land change processes towards sustainable outcomes, ensuring the provision of ecosystem services for stakeholders at different levels.

A major challenge arises if the investigation of land change starts with the analysis of remotely sensed imagery. This makes it difficult to link land cover information to human influence and thus to understand land use processes (Verburg, van de Steeg, Veldkamp, \& Willemen, 2009). This is especially pertinent in the context of shifting cultivation systems, which are characterized by a combination of different land cover types showing high spatial and temporal dynamics (Schmidt-Vogt et al., 2009; Sirén and Brondizio, 2009). Another challenge involves the discrepancy between the different levels at which land use decisions are made. Local land users' decisions are increasingly influenced by broad economic, political and environmental processes (Lambin et al., 2001; Verburg et al., 2009) leading to highly context-dependent outcomes (Ostrom, 2007; Rindfuss et al., 2007). The uniqueness of local information makes upscaling and generalization difficult (Magliocca et al., 2014), which hinders its use by policy-makers (Messerli, Bader, Hett, Epprecht, \& Heinimann, 2015). In light of these two challenges, it is not surprising that shifting cultivation in eastern Madagascar does not appear on regional or national maps. 
Most regional and national land change studies have limited their focus to the binary analysis of changes from forest to nonforest land cover (Grinand et al., 2013; Harper, Steininger, Tucker, Juhn, \& Hawkins, 2007; Ministère de l'Environnement, des Forêts et du Tourisme (MEFT), United States Agency for International Development (USAID), \& Conservation International (CI), 2009; Office National pour l'Environnement (ONE), Direction Générale des Forêts (DGF), Foiben-Taosarintanin'i Madagasikara (FTM), Madagascar National Parks (MNP) \& Conservation International (CI), 2013). The scarce scientific knowledge on the current extent and trajectories of shifting cultivation in this zone is almost exclusively based on a few case studies clustered between the capital, Antananarivo, and the port of Toamasina (Klanderud et al., 2010; Messerli, 2004; Styger et al., 2007). This presents a considerable omission given the large attention shifting cultivation has received from conservation and development stakeholders (Conservation International, 2011; Freudenberger, 2010; Holmes, Ingram, Meyers, Crowley, \& Victurine, 2008; World Bank, 2013; World Wildlife Fund, 2007).

The eastern escarpment of Madagascar holds some of the most biodiversity-rich forests on earth and is therefore a global conservation priority (Myers, Mittermeier, Mittermeier, da Fonseca, \& Kent, 2000). Theoretically, the establishment of two large protected areas in 1997 and 2005 (Masoala National Park and Makira Natural Park, respectively) has closed most of the agricultural frontier in the region. Conservation and development strategy has mainly been directed at the intensification of land use away from shifting cultivation towards permanent irrigated rice production. However, little is known about the success of this approach, and the focus on single components of the agricultural production system has been questioned (Brimont, Ezzine-de-Blas, Karsenty, \& Toulon, 2015; Messerli, 2004; Zaehringer et al., 2015). While shifting cultivators are held responsible for rapid deforestation, spatially explicit evidence for this claim is lacking due to the abovementioned difficulty of detecting shifting cultivation on land cover maps. The either/or focus on changes from forest to nonforest also limits our understanding of the processes at work and of how to slow forest loss and lift the local population out of poverty.

The goal of this study was thus to spatially delineate shifting cultivation and permanent land use systems in north-eastern Madagascar and to assess their changes at a regional level; to the best of our knowledge, it is the first such effort. For this study we defined landscape as a spatially heterogeneous area composed of interacting land use systems. We mapped current landscape types, quantified major changes in their extent from 1995 to 2011 and identified the location and magnitude of intensification and extensification at the landscape level. This offers a crucial contribution to policy-making for a more sustainable development of this resource-rich but poverty-prone region. 


\section{Materials and methods}

\subsection{The study region}

We selected our study region in north-eastern Madagascar (Figure 1) because it is home to some of the last remaining humid primary forests containing the extraordinary biodiversity for which Madagascar is known (Ganzhorn, Lowry, Schatz, \& Sommer, 2001; Myers et al. 2000). Therefore it features a number of protected areas which have the aim to halt deforestation and forest resource exploitation. We chose the administrative region of Analanjirofo as the extent of the analysis, as this is the level at which decision making for regional development takes place. However, the northernmost tip of the Analanjiorofo region is not included as the available land cover data did not extend this far. Instead, the Masoala peninsula, of which part belongs to the Sava administrative region, is included, as it represents a biodiversity hotspot of great interest to many conservation actors. 


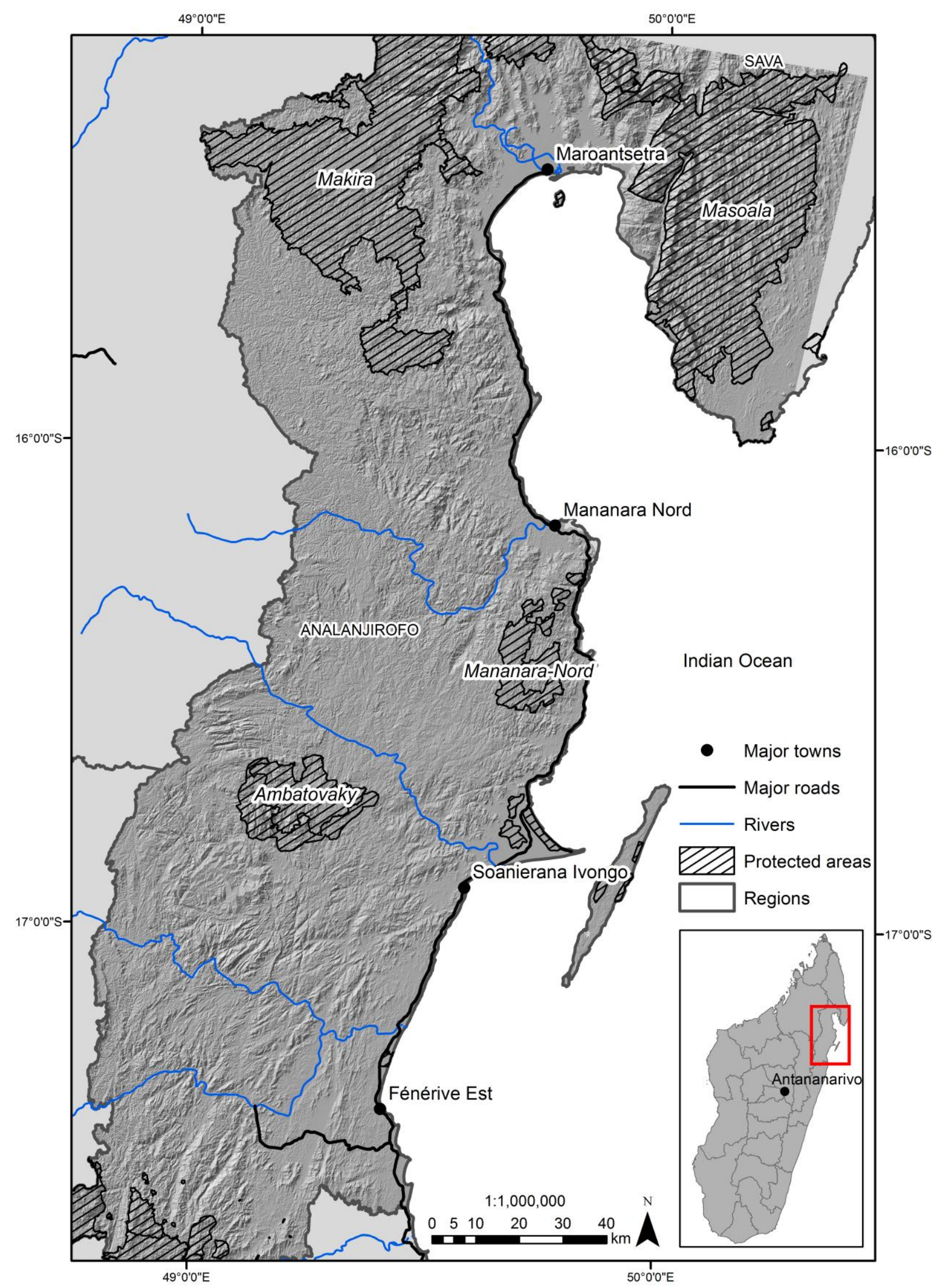

Figure 1. Study region in north-eastern Madagascar (adapted from Zaehringer, Eckert, \& Messerli, 2015). 
This region receives about $3,600 \mathrm{~mm}$ of annual precipitation and has an average annual temperature of $24^{\circ} \mathrm{C}$ (Jury, 2003). Makira Natural Park, established in 2005, encloses one of the largest continuous rainforests in the country and provides a habitat for more than 18 species of lemurs (Golden, Fernald, Brashares, Rasolofoniaina, \& Kremen, 2011). Other large forest conservation sites include Masoala National Park (established in 1997), Ambatovaky Special Reserve (established in 1958), and Mananara Nord National Park (established in 1989). Together these protected areas cover $23 \%$ of our study region (International Union for Conservation of Nature \& UNEP, 2014). Access to these forests by local land users is restricted, but due to their limited accessibility and limited funding, enforcement is rather weak.

Apart from these forests, the region is characterized by small plots with diverse land uses. Rice is the main staple crop in Madagascar. Both rain-fed upland and irrigated lowland paddy rice are produced for subsistence by the local land users, ethnically dominated by the Betsimisaraka people. Also important are commercial crops such as clove, vanilla, coffee, and lychee (Locatelli, 2000). The volatility in prices for these crops creates uncertainty for local farmers (Food and Agriculture Organization, 2014).

Traditional shifting cultivation is used to produce rain-fed upland rice on moderate to steep slopes. Most commonly land users clear and burn small plots, which they plant with rice (often in combination with maize) for a single year. Subsequently, tuber crops such as cassava or sweet potatoes are often cultivated for another one to two years. Thereafter the fields lie fallow for several years (Messerli, 2004). For permanent rice cultivation, land users need access to paddies at the valley bottoms and to irrigation water. Ploughing and weeding the irrigated rice fields is labour-intensive, and external inputs such as fertilizers are rare (Locatelli, 2000). Clove trees, coffee bushes and vanilla lianas are often grown in agroforests together with a diverse mix of fruit trees and tuber crops for home consumption. Monocultures of clove trees are also common. Zebu cattle are used for ploughing and in ancestral ceremonies. They mostly graze in irrigated rice paddies after harvest and along footpaths, as relatively few land users have sufficient land for pastures. Small forest fragments, often family owned, are dispersed throughout the region and provide construction materials, wild food, space for burial grounds and other benefits (Urech, Rabenilalana, Sorg, \& Felber, 2011).

Property rights for agricultural land are very complex in this region. Within shifting cultivation systems, all descendants of the person who first clears a forest plot have the right to use it for rice cultivation. From year to year, elders consider the land needs of households within their lineage and then allocate the plots (Urech et al., 2011). The conversion of forest into agricultural land is one of the few ways to assure food security for future descendants (Keller, 2008). The increasing scarcity of natural forests and expansion of protected areas might 
therefore incite land users to accelerate deforestation. For the cultivation of permanent agricultural land, such as irrigated rice paddies and agroforests, individual or family-based land rights usually prevail. Descendants mostly inherit these plots from their parents, while immigrants can sometimes purchase them (Messerli, 2004).

\subsection{Remote sensing data and analysis}

The land cover data used for this study were published by Zaehringer et al. (2015); only the most important methodological steps are described here. Landsat imagery was used to create land cover maps for 1995 and 2011, applying a maximum likelihood supervised classification. Both high-resolution images and field sampling data were used to verify the classification of the 2011 imagery. Accuracy assessment taking into account different map area proportions - as recommended by Olofsson, Foody, Stehman, \& Woodcock (2013) yielded an overall accuracy of $87 \%$ for the 2011 map. For the 1995 classification, no independent reference data such as aerial photos exist. However, the accuracy was estimated to be similar to that of the 2011 classification, as the same classification algorithm was applied.

The land cover classes of further interest for this article include forest (primary and degraded continuous forest and forest fragments), flooded vegetation (flooded low-growth and nonwoody vegetation), burnt plots (recently cleared and burnt plots with little or no vegetation cover), low-height vegetation (mostly non-woody vegetation such as grasses, herbaceous plants and ferns) and medium-height vegetation (primarily trees, often mixed with shrubs and large herbaceous plants). In terms of land use, flooded vegetation consists mainly of irrigated lowland paddies, while burnt plots are fields prepared for upland rice in the shifting cultivation cycle. Other minor land cover classes include bare land, grassland and water.

\subsection{Describing the landscape mosaic}

While it is possible to distinguish different land cover classes from pixel-based remote sensing images, these cannot be directly linked to land uses. To address this problem, Messerli et al. (2009) proposed a landscape mosaic approach that interprets land cover pixels by taking into account human-environment interactions and the condition of neighbouring pixels. For example, a patch of low-height vegetation, viewed in isolation, could represent several land uses, such as forest regrowth after a disturbance, a young fallow in the shifting cultivation cycle or even a pasture. But if it is surrounded by burnt plots and forest, it is probably a young fallow in a shifting cultivation system. Thus, two steps are needed to derive landscape types from land cover data: identification of land cover patterns, or mosaics, and their contextual interpretation. 
Hett et al. (2012), studying shifting cultivation in northern Laos, further developed this approach in two ways: using a hierarchical decision tree to classify landscape types, and analysing change by comparing landscape mosaic maps of two points in time. This addressed a problem associated with studying shifting cultivation landscapes. These landscapes, consisting of cultivated plots in a matrix of fallows at different regrowth stages, with the location of each plot changing every year, are difficult to delineate with pixel-based approaches. The following sections show how we applied the landscape mosaic approach developed in Laos to the context of north-eastern Madagascar to describe and quantify landscape types.

For the first step, we used a moving window technique in ArcGIS to provide every pixel in the land cover map with information about the composition of neighbouring pixels, with the size of the neighbourhood (and moving window) set to reflect the average area influenced by an individual land user. Based on interview data collected by Zaehringer (2014, unpublished), we assessed the range of influence of land users at a maximum of about $2.5 \mathrm{~km}$ from the home village. We therefore set the size of the moving window to $5 \times 5 \mathrm{~km}$. The proportion of each land cover class on the total $25 \mathrm{~km}^{2}$ neighbourhood area was attributed to the pixel (equivalent to $30 \times 30 \mathrm{~m}$ of land) at the window centre.

In the second step, the land cover mosaics were interpreted in order to extract information on land use (Messerli et al., 2009) at a larger scale. This interpretation took into account the socio-ecological context (as established in extensive field studies by the authors) and was guided by two land use issues that are important for conservation and development in the region:

1. Intensity of staple crop cultivation: Land users in the study region rely heavily on the cultivation of subsistence rice, as the income from cash crops is highly variable and market accessibility low. Therefore, the presence or absence of rice fields is a reliable indicator of agricultural land use in this region. We use the term intensification to describe a change in land use from shifting cultivation to irrigated rice production and the term extensification for the opposite process. Intensification and extensification can also occur within a single land use system-for example, by changing fallow duration in shifting cultivation systems or the number of times irrigated rice is cultivated per year-but these are not detected through our approach.

2. Proportion of tree cover: While at the global level the forests of north-eastern Madagascar are highly valued for the benefits of carbon sequestration and biodiversity maintenance (Holmes et al., 2008; Kremen et al., 2000), local land users value the forests primarily as potential future agricultural land (Keller, 2008) and as a 
source of goods necessary for their well-being (Golden, Bonds, Brashares,

Rasolofoniaina, \& Kremen, 2014; Urech et al., 2011). The high international demand for precious woods and their illegal exploitation (Schuurman \& Lowry, 2009) adds another challenge to forest maintenance. Tree cover exists not only in forests but also on smallholders' cultivated land. Clove trees (Syzygium aromaticum) provide the main cash crop, and many other tree species such as lychee (Litchi chinensis), breadfruit (Artocarpus altilis) and jackfruit (Artocarpus heterophyllus) deliver important food supplements (Pfund et al., 2011).

A matrix of landscape types, based on these two land use issues, was developed (Figure 2). The criteria describing each of the landscape types were translated into conditional statements executed in ArcGIS. Two maps were generated, with every pixel in the land cover map assigned, first, to one of five classes of staple crop cultivation, and second, to one of three classes of tree cover, depending on the composition of land cover classes in its neighbourhood. Finally, the two maps were intersected to produce one map with all 15 landscape types.

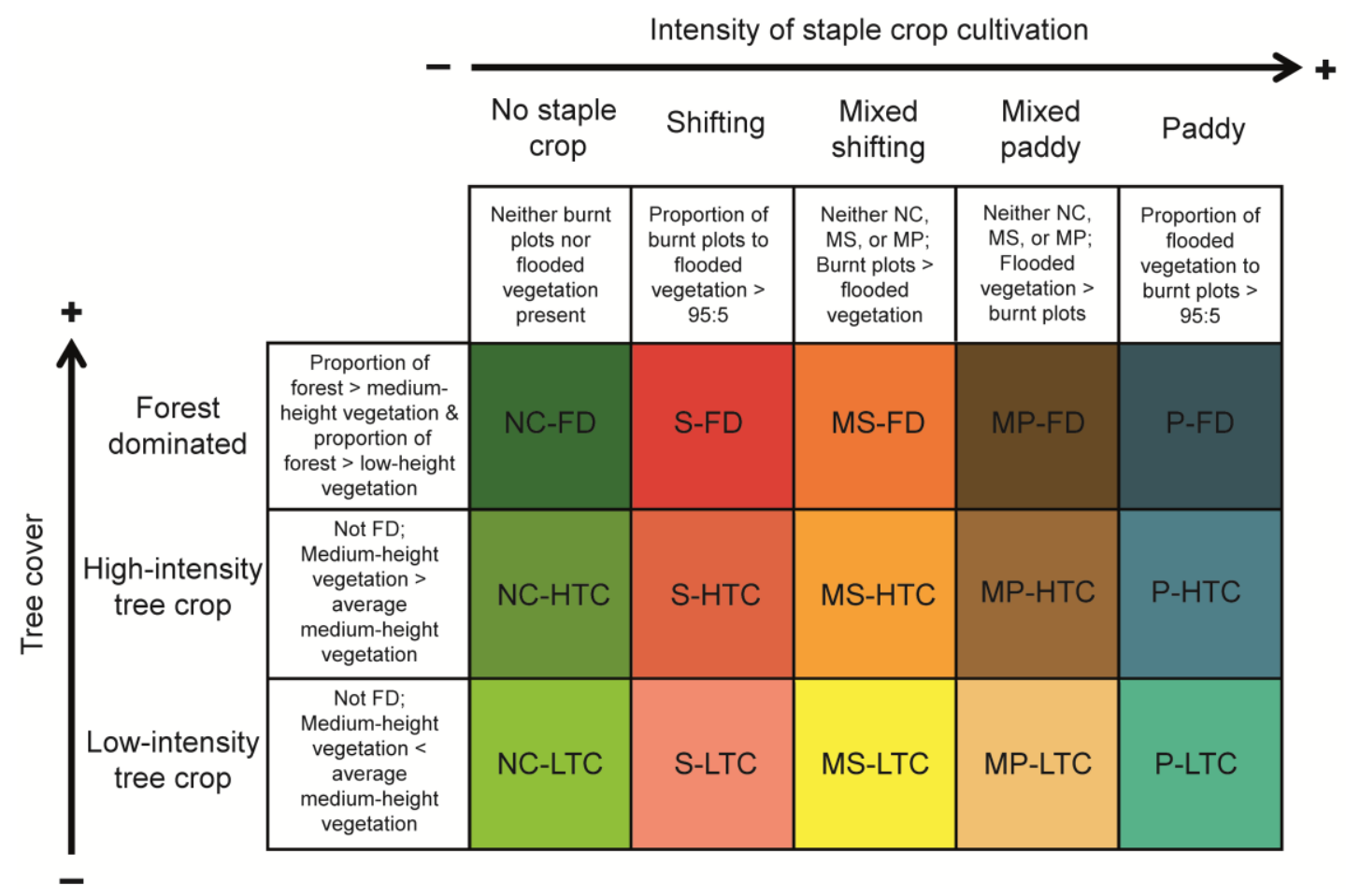

Figure 2. Landscape types categorized by staple crop intensity and tree cover. (FD = forest dominated, HTC = high-intensity tree crop, LTC = low-intensity tree crop, NC = no staple crop, $S=$ shifting, $M S=$ mixed shifting, $M P=$ mixed paddy,$P=$ paddy $)$.

Along the gradient of staple crop intensity, we classified pixels as follows: 
- Those without either burnt plots or flooded vegetation in their neighbourhoods were classified as no staple crop. This landscape type contains only forest and mediumand low-height vegetation.

- A strong domination of burnt plots over flooded vegetation was classified as shifting cultivation. A threshold of 95:5 was chosen to allow for the presence of single pixels resulting from wrongly classified flooded vegetation in the land cover map.

- A strong domination of flooded vegetation over burnt plots was classified as paddy cultivation, with the same threshold.

- The remaining area, which contained both shifting and paddy cultivation, was classified as mixed shifting or mixed paddy depending on whether burnt plots or flooded vegetation, respectively, predominated.

Along the tree cover gradient, we classified pixels as follows:

- Those for which forest covered more of their neighbourhoods than either medium- or low-height vegetation were classified as forest dominated.

- The remaining pixels were classified as high-intensity tree crop if their neighbourhoods' share of medium-height vegetation was higher than the average for the entire analysed area, and otherwise as low-intensity tree crop. These two labels were deemed adequate because the medium-height vegetation in the area consists mainly of clove and fruit trees (Zaehringer et al., 2015).

The resulting landscape mosaic maps represent aggregated land use information at the landscape level. Pixels featuring a similar composition of land cover categories in their neighbourhood are classified as the same landscape type. For landscape-level assessments in general, an error assessment is not possible. However, single pixel classification errors in the land cover maps used as an input do not weigh.

The land cover maps contained substantial areas for which no data were available due to cloud cover. Thus, if a pixel's $5 \times 5 \mathrm{~km}$ neighbourhood contained more than $70 \%$ "no data" pixels, the pixel was classified as "no data" in the landscape mosaic map as well. The nodata area in the landscape mosaic map covered about $15 \%$ of the total study region. The remaining area amounted to $20,507 \mathrm{~km}^{2}$ and is referred to in this article as the analysed area. 


\subsection{Analysing landscape change}

The landscape mosaic approach enables the detection of changes affecting entire land use systems instead of single land cover pixels. This is particularly useful when investigating changes in shifting cultivation systems, characterized by annual rotations of crop fields and fallows. In a land cover change map, such dynamics would appear on single pixels as yearto-year deforestation and regrowth. In contrast, using the landscape mosaic approach, such changes inherent to the character of a shifting cultivation land use system will not appear. This allows for the monitoring of overall changes between shifting cultivation and other land use systems over time. To analyse landscape change, we classified transitions from one landscape type to another according to changes in staple crop intensity and tree cover (Figure 3). Change processes were then quantified by overlaying the landscape mosaic maps from 1995 and 2011 in ArcGIS.

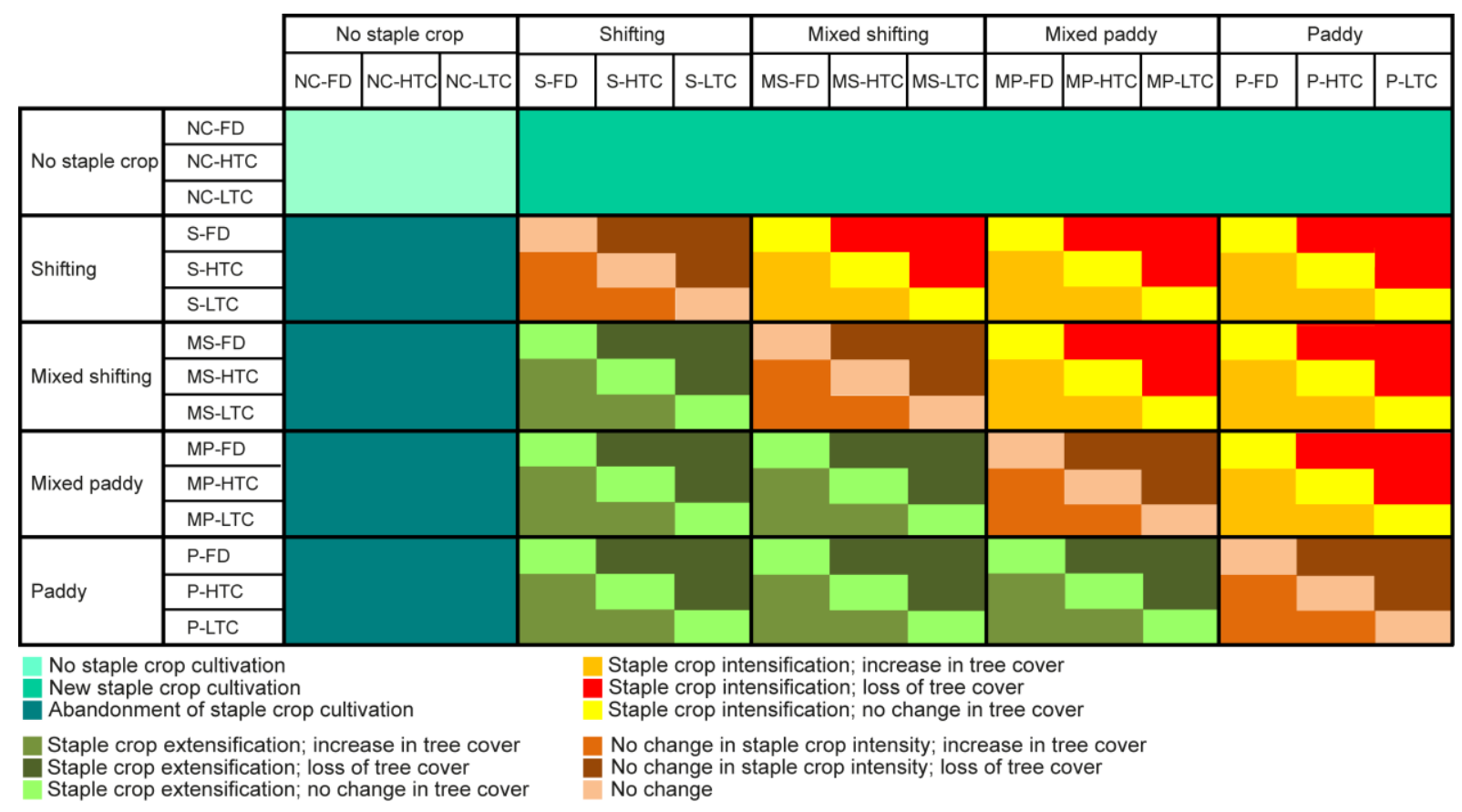

Figure 3. Classification of landscape change processes based on the matrix of landscape types. (FD = forest dominated, HTC = high-intensity tree crop, LTC = low-intensity tree crop, NC = no staple crop, $\mathrm{S}=$ shifting, $\mathrm{MS}=$ mixed shifting, $\mathrm{MP}=$ mixed paddy, $\mathrm{P}=$ paddy).

A change towards more irrigated rice cultivation was termed land use intensification, whereas the opposite process was termed land use extensification. Changes from areas without staple crop cultivation to any intensity of staple crop cultivation were termed new staple crop cultivation. Abandonment of staple crop cultivation was considered to have occurred when areas formerly cultivated with staple crops no longer showed signs of cultivation. Whenever low-intensity tree crop changed to high-intensity tree crop or forest dominated, we considered this an increase of tree cover, and loss of tree cover occurred if the opposite was the case. 


\section{Results}

\subsection{Current landscapes in the study region}

While the pixel-level differentiation between land cover classes makes it hard to visually apprehend different agricultural categories on the land cover map, the landscape mosaic map makes it easy to distinguish them (Figure 4).
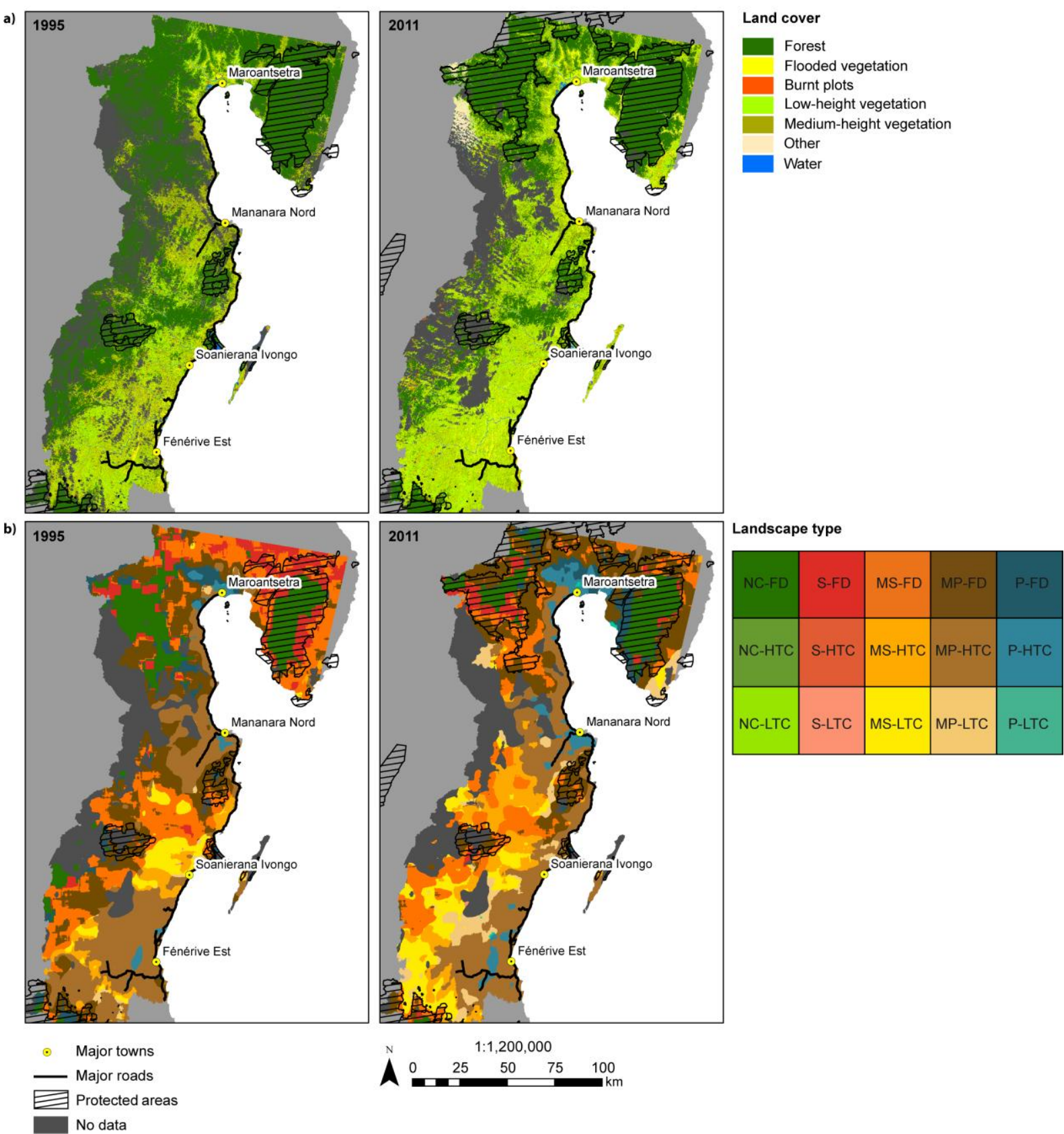

Figure 4. a) Land cover maps (adapted from Zaehringer et al., 2015) and b) landscape mosaic maps for 1995 and 2011. (FD = forest dominated, HTC = high-intensity tree crop, LTC = lowintensity tree crop, $\mathrm{NC}=$ no staple crop, $\mathrm{S}=$ shifting, $\mathrm{MS}=$ mixed shifting, MP = mixed paddy, $\mathrm{P}$ $=$ paddy). 
While in 2011, about half of the analysed area had forest-dominated tree cover, all but about $7 \%$ showed signs of at least some agricultural use, e.g. single shifting-cultivation plots (Figure 5). Although forest cover was still widespread in 2011 (see figure 4, left), much of it existed in fragments smaller than $5 \times 5 \mathrm{~km}$, dispersed throughout the study region. Large continuous forest areas without any sign of agricultural use were limited to the core zones of Masoala and Makira protected areas in the north of the study region. The other two tree cover categories, high- and low-intensity tree crops, only existed in combination with staple crop production and covered $35 \%$ and $13 \%$ of the analysed area, respectively.

Landscapes where rice was produced only through shifting cultivation covered only $3 \%$ of the analysed area in 2011. These landscapes were almost exclusively forest dominated and encircled the forest-dominated landscapes without staple crop production, mainly in the Makira Natural Park and along the eastern border of Masoala National Park. Mixed agricultural landscapes dominated by shifting cultivation were common and covered the interior of the study region towards the highlands. They were mostly forest dominated, especially in the northern part of the study region. Almost half of the study region was covered with mixed agricultural landscapes dominated by paddy rice production. In terms of vegetation cover, these landscapes were about equally dominated by forest and highintensity tree crops. While the mixed paddy landscapes dominated by forest were common surrounding the protected areas, the ones dominated by high-intensity tree crops occurred all along the coast between the cities of Maroantsetra and Fénérive Est. Landscapes entirely based on paddy rice production were only present in $8 \%$ of the analysed area and limited to the plains around Maroantsetra and Mananara Nord and along the western border of Masoala National Park. While in the plains they were associated with high-intensity tree crops, along the protected area boundary they were forest dominated.

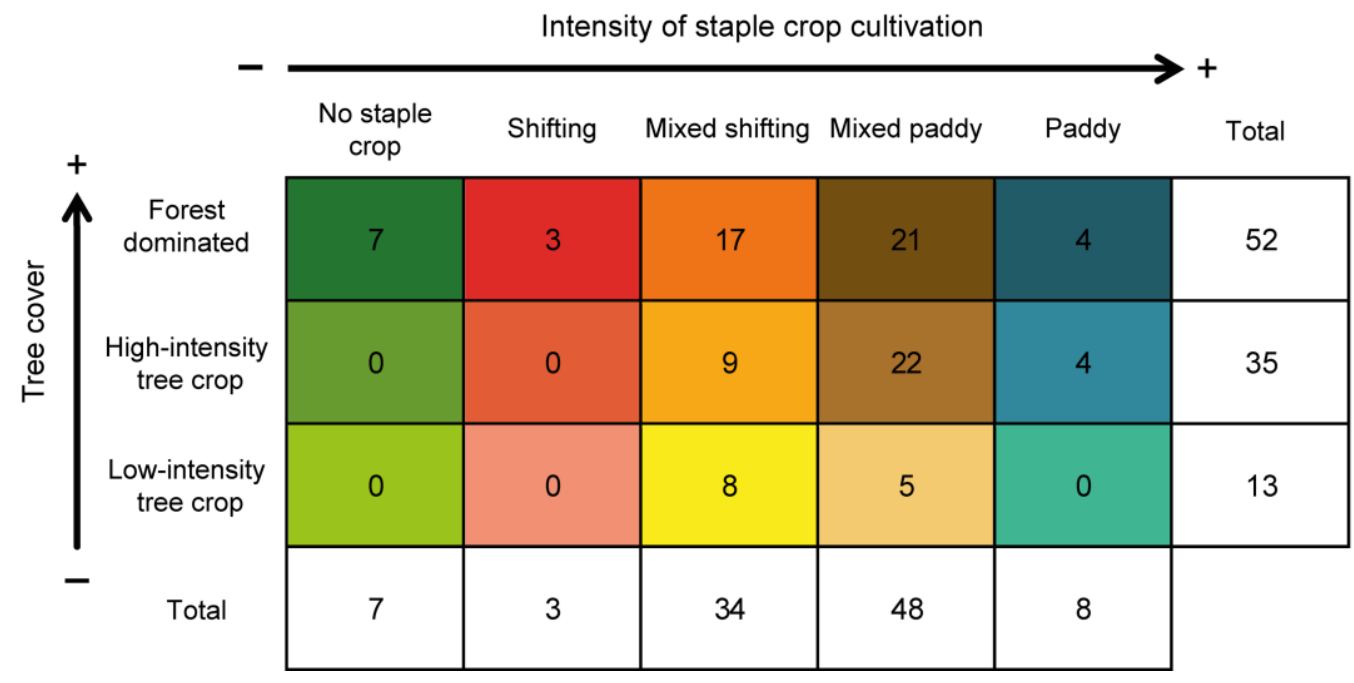

Figure 5. Landscape types as percentage of total analysed area in 2011. 


\subsection{Landscape change from 1995 to 2011}

In 1995, forest-dominated landscapes without any sign of staple crop cultivation were still quite widespread in the northern part of the study region. By 2011 they had decreased considerably, especially in the southern part of what today is the Makira Natural Park. The edges of the Masoala National Park were dominated by shifting cultivation in 1995, which had intensified into mixed paddy cultivation by 2011. In 1995, the middle part of the study region was covered with forest-dominated, mixed shifting cultivation landscapes. In this area from 1995 to 2011 the main change was a degradation of tree cover, which also occurred in mixed paddy cultivation landscapes in the southern part of the region (Figure 6).

In general, between 1995 and 2011, landscapes with no staple crop production and landscapes based entirely on shifting cultivation decreased, while the mixed and paddybased landscapes increased (Figure 6). Mixed landscapes had already covered by far the largest share of the study region in 1995. Forest-dominated landscapes decreased for all levels of staple crop intensity.

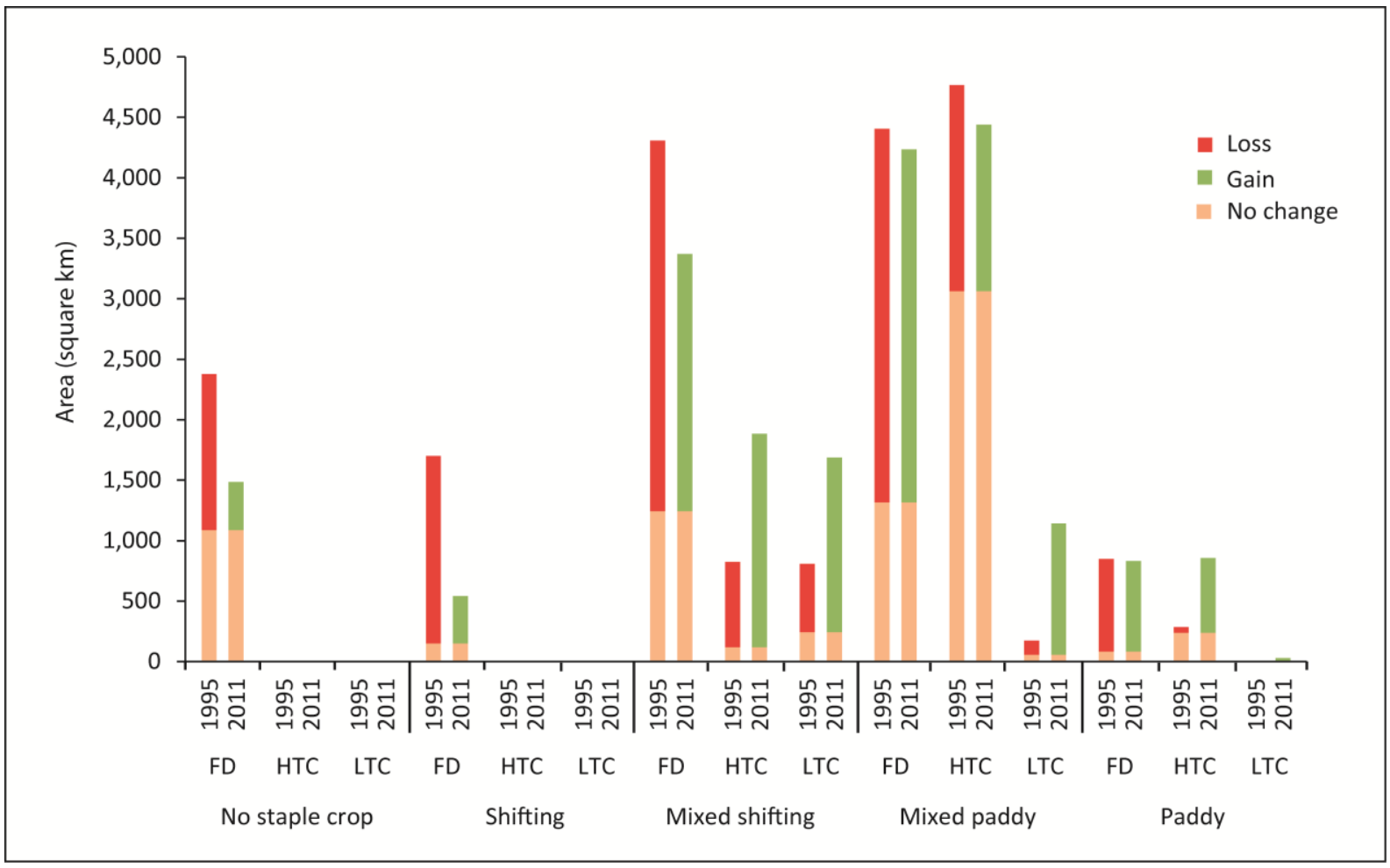

Figure 6. Stable areas, losses and gains in area for each landscape type, 1995 to 2011. The difference between the heights of the bars within each landscape type represents net change whereas overlapping losses and gains represent swap change. Where there is no value, the landscape type did not exist in the respective year. (FD = forest dominated, HTC = highintensity tree crop, LTC = low-intensity tree crop). 
Mixed shifting cultivation landscapes with a high intensity of tree crops experienced the greatest net increase. Mixed paddy landscapes with a low intensity of tree crops experienced the second largest net increase, followed by mixed shifting cultivation landscapes with a low intensity of tree crops. Large net decreases were experienced by forest-dominated landscapes, mainly those based on shifting and mixed shifting cultivation. The least humaninfluenced landscape type, forest-dominated landscapes without staple crop production, decreased. The small gain of forest-dominated landscapes without staple crop production that occurred elsewhere can be explained by single shifting cultivation rice fields established in the interior of the Masoala and Makira National Parks before 1995, which had disappeared by 2011 . Some landscape mosaics that experienced small net changes, such as the mixed agricultural landscapes, experienced large "swaps" (simultaneous gains and losses occurring in different areas-Pontius, Shusas, \& McEachern, 2004). The most stable landscape type in terms of both net change and swap was the mixed paddy landscape dominated by highintensity tree crops.

The forest-dominated landscapes without staple crop cultivation were transformed mainly into mixed shifting cultivation landscapes (Figure 7). Shifting cultivation and mixed shifting cultivation landscapes were both changed into mixed paddy landscapes, while forest remained the dominant tree cover. The opposite change, from mixed paddy to mixed shifting cultivation, was also common and occurred mainly in forest-dominated landscapes. Forestdominated paddy-based landscapes mainly experienced a change into mixed paddy landscapes. Within mixed shifting cultivation and mixed paddy landscapes, degradation of tree cover from forest to high- or low-intensity tree crop or from high- to low-intensity tree crop was very common. The change from mixed shifting cultivation to mixed paddy landscapes was often associated with an increase in tree cover from low- to high-intensity tree crop. The same was true within mixed shifting cultivation landscapes where the change from low- to high-intensity tree crop was widespread. 


\begin{tabular}{|c|c|c|c|c|c|c|c|c|c|c|c|c|c|c|c|c|c|}
\hline & & & \multicolumn{15}{|c|}{2011} \\
\hline & & & \multicolumn{3}{|c|}{ No staple crop } & \multicolumn{3}{|c|}{ Shifting } & \multicolumn{3}{|c|}{ Mixed shifting } & \multicolumn{3}{|c|}{ Mixed paddy } & \multicolumn{3}{|c|}{ Paddy } \\
\hline & & & FD & HTC & LTC & FD & HTC & LTC & FD & HTC & LTC & FD & HTC & LTC & FD & HTC & LTC \\
\hline \multirow{15}{*}{1995} & \multirow{3}{*}{$\begin{array}{l}\text { No } \\
\text { staple } \\
\text { crop }\end{array}$} & FD & 1,087 & 0 & 0 & 279 & 0 & 0 & 531 & 0 & 3 & 394 & 0 & 2 & 81 & 0 & 0 \\
\hline & & HTC & 0 & 0 & 0 & 0 & 0 & 0 & 0 & 0 & 0 & 0 & 0 & 0 & 0 & 0 & 0 \\
\hline & & LTC & 0 & 0 & 0 & 0 & 0 & 0 & 0 & 0 & 0 & 0 & 0 & 0 & 0 & 0 & 0 \\
\hline & \multirow{3}{*}{ Shifting } & FD & 289 & 0 & 0 & 149 & 0 & 0 & 356 & 4 & 1 & 687 & 24 & 16 & 175 & 0 & 0 \\
\hline & & HTC & 0 & 0 & 0 & 0 & 0 & 0 & 0 & 1 & 0 & 0 & 2 & 0 & 0 & 0 & 0 \\
\hline & & LTC & 0 & 0 & 0 & 0 & 0 & 0 & 0 & 3 & 0 & 0 & 1 & 0 & 0 & 0 & 0 \\
\hline & \multirow{3}{*}{$\begin{array}{l}\text { Mixed } \\
\text { shifting }\end{array}$} & FD & 22 & 0 & 0 & 30 & 0 & 0 & 1,245 & 530 & 409 & 1,537 & 139 & 131 & 265 & 1 & 0 \\
\hline & & HTC & 0 & 0 & 0 & 0 & 0 & 0 & 0 & 120 & 185 & 0 & 429 & 87 & 0 & 0 & 0 \\
\hline & & LTC & 0 & 0 & 0 & 0 & 0 & 0 & 0 & 332 & 244 & 4 & 157 & 72 & 0 & 0 & 0 \\
\hline & \multirow{3}{*}{$\begin{array}{l}\text { Mixed } \\
\text { paddy }\end{array}$} & $\mathrm{FD}$ & 18 & 0 & 0 & 47 & 0 & 1 & 1,017 & 484 & 491 & 1,318 & 490 & 274 & 223 & 32 & 10 \\
\hline & & HTC & 0 & 0 & 0 & 0 & 0 & 5 & 0 & 381 & 328 & 13 & 3,062 & 501 & 4 & 468 & 7 \\
\hline & & LTC & 0 & 0 & 0 & 0 & 0 & 0 & 0 & 26 & 24 & 0 & 60 & 58 & 0 & 4 & 2 \\
\hline & \multirow{3}{*}{ Paddy } & FD & 70 & 0 & 0 & 37 & 0 & 0 & 222 & 2 & 1 & 282 & 37 & 0 & 83 & 111 & 2 \\
\hline & & HTC & 0 & 0 & 0 & 0 & 0 & 0 & 0 & 0 & 0 & 0 & 39 & 0 & 0 & 238 & 7 \\
\hline & & LTC & 0 & 0 & 0 & 0 & 0 & 0 & 0 & 0 & 0 & 0 & 0 & 0 & 0 & 2 & 1 \\
\hline
\end{tabular}

FD = forest dominated; HTC = high-intensity tree crop; LTC = low-intensity tree crop.

Figure 7. Landscape type transitions in the analysed area $\left(\mathrm{km}^{2}\right), 1995$ to 2011.

\subsection{Intensification and extensification}

To better understand the importance of different landscape change trajectories, we aggregated the transitions between single landscape types (Figure 7) according to the schema presented in Figure 3. About one-third of the analysed area did not undergo any landscape change from 1995 to 2011 (Figure 8). By far the most common change was staple crop intensification (more irrigated rice paddies or fewer shifting cultivation plots) without any change in tree cover. This occurred primarily around the Masoala National Park in the north of the study region as well as in the coastal area around Soanierana Ivongo. No change in staple crop intensity but a loss of tree cover was the second most common change trajectory, mainly observed towards the western border of the study region. Staple crop extensification (more shifting cultivation plots or fewer irrigated paddies) was also observed in the interior of the region towards the highlands as well as along the southern edge of Makira Natural Park, with and without loss of tree cover. Most new staple crop cultivation occurred in forest-dominated areas in the southwestern part of Makira Natural Park. Other landscape change trajectories were less common. 

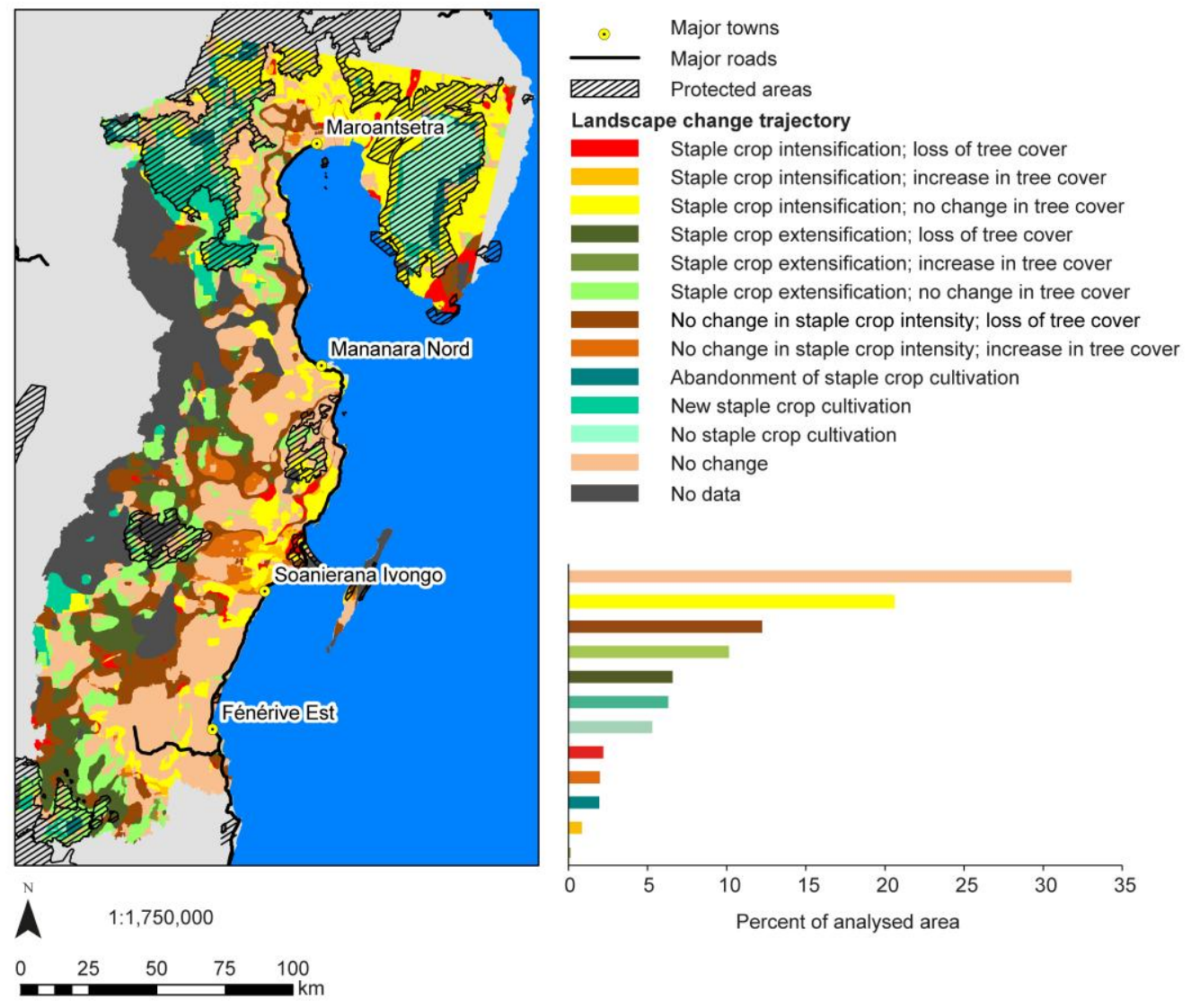

Figure 8. Detailed landscape change trajectories in the study region and in percent of total analysed area, 1995 to 2011.

\section{Discussion}

\subsection{Delineating shifting and permanent cultivation systems}

Landscapes in which rice is produced only through shifting cultivation were rare in 2011 and limited to forested areas, mainly in Makira Natural Park. These areas are hotspots of pioneering shifting cultivation (Castella et al., 2012), where people acquire agricultural land by establishing rice fields in forests. For many land users in our study region, this is still the only way to secure land for their families and descendants (Keller, 2008). While in 1995 the borders of the Masoala forest were dominated by pioneering shifting cultivation, these areas had transformed into mixed paddy landscapes by 2011. However, shifting cultivation is still present in $85 \%$ of the study region (see Figure 5).

Mixed land use, in which rice is produced through both shifting and paddy cultivation, predominates in north-eastern Madagascar. More than $80 \%$ of the region is still characterized by a high tree cover that includes both forests and planted fruit trees. This reflects the diverse local strategies to use available labour and land resources to produce as much rice for subsistence as possible as well as cash crops such as clove and vanilla 
(Brimont et al., 2015; Cullman, 2015; Locatelli, 2000; Urech et al., 2011). Diversification reduces vulnerability to crop loss during cyclones, which are common in this region (Birkinshaw and Randrianjanahary, 2007; Harvey et al., 2014). Towards the coast, these mixed systems are dominated more by irrigated rice production than by shifting cultivation. This is probably a result of both flatter topography, which facilitates the establishment of irrigated paddies, and better access to major towns. The transformation from forests to agricultural land began in the coastal areas. From there, the deforestation frontier, dominated by shifting cultivation, has gradually advanced towards the interior. Coastal mixed paddy landscapes are characterized by a dense cover of tree crops, primarily clove, coffee and lychee. Pure paddy cultivation has increased since 1995 and now covers the plains around the district capitals of Maroantsetra and Mananara Nord.

An area without urban centres and large floodplains where paddy rice cultivation nonetheless flourishes is the western boundary of Masoala National Park in the Ambanizana River valley; in 2011 only paddy rice was produced in this area. This might be due to greater law enforcement by park wardens due to the area's relative ease of access from Maroantsetra compared to other parts of the Masoala peninsula. Land users in Ambanizana are aware of the heavy fines for slashing and burning vegetation inside the protected area (Keller, 2008) and might therefore abstain from shifting cultivation. Although from the point of view of the national park management this might present a favourable outcome, it should not be regarded as a sustainable solution to curb deforestation, as in moments of reduced law enforcement land users are likely to continue clearing land. Further, the prohibition for land users to produce rice through shifting cultivation on their ancestral land, now included in the national park, has reportedly driven affected families deeper into poverty (Keller, 2015). In other locations in the cores of the protected areas of Makira and Masoala, staple crop cultivation has been abandoned altogether. However, these forests face other considerable threats as well, such as the illegal harvest of rosewood for the international market (Caramel, 2015; Randriamalala and Liu, 2010; Schuurman \& Lowry, 2009).

\subsection{Evidence of intensification}

Staple crop intensification (a move from shifting to paddy cultivation) without a change in tree cover was the most common change in the study region between 1995 and 2011. This took place mainly in the surroundings of the Masoala National Park. We therefore hypothesize that intensification was induced by the restricted access to new land for shifting cultivation. This could be considered a desired outcome of the protected-area strategy (Phalan, Onial, Balmford, \& Green, 2011). The second most common change, which occurred throughout the interior and more remote part of the region, was the loss of tree cover while staple crop production remained stable. As the two change processes of staple crop intensification and 
loss of tree cover hardly occurred together, this indicates that trade-offs between more intensive staple crop production and the maintenance of tree cover at the landscape level were limited. An exception was observed on the southern tip of the Masoala peninsula though, where intensification occurred with simultaneous vegetation degradation from forest to low-intensity tree crops. Such a change process at landscape level away from shifting cultivation towards more irrigated rice production might have various consequences for ecosystem service provision, for example with respect to carbon sequestration, as longfallow shifting cultivation could raise carbon stocks at the landscape level (Mertz et al., 2009). While tree cover remains high in most of the region and landscapes still contain many seminatural features such as forest fragments and agroforests, a reduction of tree cover might be the next step following the intensification of staple crop cultivation.

At least at the regional level, the observed intensification at landscape level seems to contradict the common narrative (Kull, 2000) that population growth and increased poverty lead to increased shifting cultivation and thus deforestation. While population in the Analanjirofo region increased by about 54\% from 1995 to 2011 (Institut National de la Statistique de Madagascar, 2011), the share of the poor rural population in Madagascar (based on the national poverty line) increased from 70.8\% to 75.3\% between 2001 and 2010 (World Bank, 2015). Our findings rather support the observations by Kull (1998) in the Malagasy highlands and Laney (2002) in the Andapa Valley that when access to resources is constrained, population increase can lead to intensification rather than degradation of agricultural land.

\subsection{Potential of the landscape mosaic approach for land use planning in Madagascar}

The landscape mosaic approach allowed us to delineate shifting cultivation and permanent land use systems using basic land cover information. With this approach, although the precise land cover at the location of each single pixel is lost, knowledge is gained about land use by interpreting the spatial combination of different land cover pixels within a defined neighbourhood. Land use patterns delineated in this way are also easier to see than those in a standard land cover map (see Figure 4).

North-eastern Madagascar is one of the key priorities for conservation in the country and hosts the first REDD+ project in Africa, which generates revenues from government-owned carbon credits (Brimont et al., 2015). In this context, it will be crucial to monitor changes in land use and to understand the effects of these interventions on both agricultural intensification and reforestation. The landscape mosaic approach enables identification of hotspots of land use change and thus provides evidence on which land use planning and forest conservation can build. 


\section{Conclusion}

Using the landscape mosaic approach, we revealed hotspots of shifting cultivation and a trend towards staple crop intensification in north-eastern Madagascar. Shifting cultivation is still an important livelihood strategy, present to some degree in about $85 \%$ of the region. This regional-level evidence adds to the scarce existing knowledge on the trajectories of shifting cultivation from local-level case studies in this biodiversity hotspot. From our analysis we can conclude that (1) in north-eastern Madagascar today, mixed shifting and permanent paddy rice cultivation predominate, with a relatively high cover of tree crops, (2) areas where rice was produced only through shifting cultivation have almost disappeared since 1995 and (3) intensification from shifting to paddy cultivation has been the most common change since 1995 and has occurred mainly in the vicinity of protected areas. Landscapes without any obvious agricultural activities and with continuous forest cover are limited to the core zones of the two largest protected areas, Masoala and Makira. To protect the forests while simultaneously increasing local land users' well-being, it is necessary to better understand the socio-ecological systems that shape these landscapes. In particular, factors influencing land users' access to and ability to cultivate irrigable land need to be recognized and considered in planning. Although we saw that mixed agricultural landscapes prevail, we do not know how great a proportion of land users are pursuing mixed rice cultivation and how many continue to depend fully on shifting cultivation. This knowledge will be crucial to developing conservation and development interventions that benefit all land users equally and thus help prevent the further conversion of forest to agricultural land.

\section{Acknowledgements}

This research was supported by the Centre for Development and Environment and the Institute of Geography, University of Bern, Switzerland; the Eastern and Southern Africa Partnership Programme, supported by the Swiss Agency for Development and Cooperation; as well as the Swiss Programme for Research on Global Issues for Development, supported by the Swiss National Science Foundation and the Swiss Agency for Development and Cooperation, grant number 400440 152167. We thank Amanda Morgan for editing.

\section{References}

Birkinshaw, C., \& Randrianjanahary, M. (2007). The effects of Cyclone Hudah on the forest of Masoala peninsula, Madagascar. Madagascar Conserv. \& Dev. 2 (1), 17-20. doi: $10.4314 / 235$ 
Brimont, L., Ezzine-de-Blas, D., Karsenty, A., \& Toulon, A. (2015). Achieving conservation and equity amidst extreme poverty and climate risk: The Makira REDD+ project in Madagascar. Forests 6 (3), 748-768. doi:10.3390/f6030748.

Caramel, L. (2015). China's rosewood craving cuts deep into Madagascar rainforests. Guardian, February 16. Retrieved from http://www.theguardian.com/environment/2015/feb/16/rosewood-madagascar-chinaillegal-rainforest. Last accessed: 15.06.2015.

Castella, J.-C., Lestrelin, G., Hett, C., Bourgoin, J., Fitriana, Y. R., Heinimann, A., \& Pfund, J.-L. (2012). Effects of landscape segregation on livelihood vulnerability: Moving from extensive shifting cultivation to rotational agriculture and natural forests in northern Laos. Human Ecology 41 (1), 63-76. doi:10.1007/s10745-012-9538-8.

Conservation International. (2011). Restauration forestière à Madagascar. Capitalisation des expériences en vue de l'élaboration d'un plan d'action de restauration. Antananarivo, Madagascar: MacArthur and Conservation International.

Cullman, G. (2015). Community forest management as virtualism in northeastern Madagascar. Human Ecology 43 (1), 29-41. doi:10.1007/s10745-015-9725-5.

DeFries, R. S., Rudel, T., Uriarte, M., \& Hansen, M. (2010). Deforestation driven by urban population growth and agricultural trade in the twenty-first century. Nature Geoscience 3 (3), 178-181. doi:10.1038/NGEO756.

Food and Agriculture Organization of the United Nations. (2014). FAOSTAT. Retrieved from http://faostat3.fao.org. Last accessed: 15.12.2015.

Freudenberger, K. (2010). Paradise lost? Lessons from 25 years of USAID environment programs in Madagascar. Washington, DC: International Resources Group.

Ganzhorn, J. U., Lowry, P. P., Schatz, G. E., \& Sommer, S. (2001). The biodiversity of Madagascar: One of the world's hottest hotspots on its way out. Oryx 35 (4), 346348. doi:10.1046/j.1365-3008.2001.00201.x.

Gibbs, H. K., Ruesch, A. S., Achard, F., Clayton, M. K., Holmgren, P., Ramankutty, N., \& Foley, J. A. (2010). Tropical forests were the primary sources of new agricultural land in the 1980s and 1990s. Proceedings of the National Academy of Sciences 107 (38), 16732-16737. doi:10.1073/pnas.0910275107.

Global Land Project. (2005). Science plan and implementation strategy. Report No. 53, International Geosphere-Biosphere Programme. Stockholm: IGBP Secretariat. 
Golden, C. D., Fernald, L.C.H., Brashares, J. S., Rasolofoniaina, B.J.R., \& Kremen, C. (2011). Benefits of wildlife consumption to child nutrition in a biodiversity hotspot. Proceedings of the National Academy of Sciences of the United States of America 108 (49), 19653-19656. doi:10.1073/pnas.1112586108.

Golden, C. D., Bonds, M. H., Brashares, J. S., Rasolofoniaina, B.J.R., \& Kremen, C. (2014). Economic Valuation of Subsistence Harvest of Wildlife in Madagascar. Conservation Biology, 28 (1), 234-243. doi:10.1111/cobi.12174

Grinand, C., Rakotomalala, F., Gond, V., Vaudry, R., Bernoux, M., \& Vieilledent, G. (2013). Estimating deforestation in tropical humid and dry forests in Madagascar from 2000 to 2010 using multi-date Landsat satellite images and the random forests classifier. Remote Sensing of Environment 139 (0), 68-80. doi:10.1016/j.rse.2013.07.008.

Harper, G. J., Steininger, M. K., Tucker, C. J., Juhn, D., \& Hawkins, F. (2007). Fifty years of deforestation and forest fragmentation in Madagascar. Environmental Conservation 34 (4), 325-333. doi:10.1017/s0376892907004262.

Harvey, C. A., Rakotobe, Z. L., Rao, N. S., Dave, R., Razafimahatratra, H., Rabarijohn, R. H., Rajaofara, H., \& MacKinnon, J. L. (2014). Extreme vulnerability of smallholder farmers to agricultural risks and climate change in Madagascar. Philosophical Transactions of the Royal Society of London B: Biological Sciences 369 (1639), 1-12. doi:10.1098/rstb.2013.0089.

Hett, C., Castella, J.-C., Heinimann, A., Messerli, P., \& Pfund, J.-L. (2012). A landscape mosaics approach for characterizing swidden systems from a REDD+ perspective. Applied Geography 32 (2), 608-618. doi:10.1016/j.apgeog.2011.07.011.

Holmes, C., Ingram, J. C., Meyers, D., Crowley, H., \& Victurine, R. (2008). Case study. Forest carbon financing for biodiversity conservation, climate change mitigation and improved livelihoods: The Makira Forest Protected Area, Madagascar. Bronx, NY: Wildlife Conservation Society, TransLinks Program. Retrieved from http://theredddesk.org/resources/case-study-forest-carbon-financing-biodiversityconservation-climate-change-mitigation-and. Last accessed: 15.12.2015.

Humbert, H. (1927). Principaux aspects de la végétation à Madagascar. La destruction d'une flore insulaire par le feu. Fascicule V. Antananarivo, Madagascar: Mémoires de l'Academie Malgache.

Ickowitz, A. (2006). Shifting cultivation and deforestation in tropical Africa: Critical reflections. Development and Change 37 (3), 599-626. doi:10.1111/j.0012-155X.2006.00492.x. 
Institut National de la Statistique de Madagascar. (2011). Population Madagascar 19932011. Retrieved from http://instat.mg/category/population/. Last accessed: 27.05.2015.

International Union for Conservation of Nature \& United Nations Environment Programme. (2014). The world database on protected areas. Retrieved from http://www.protectedplanet.net. Last accessed: 27.05.2015.

Jury, M. R. (2003). The climate of Madagascar. In S. M. Goodman and J. P. Benstead (Eds.), The natural history of Madagascar (pp. 5-87). Chicago and London: University of Chicago Press.

Keller, E. (2015). Beyond the lens of conservation. Malagasy and Swiss imaginations of one another. New York, Oxford: Berghahn. ISBN 978-1-78238-552-3.

Keller, E. (2008). The banana plant and the moon: Conservation and the Malagasy ethos of life in Masoala, Madagascar. American Ethnologist 35 (4), 650-664. doi: 10.1111/j.1548-1425.2008.00103.x

Klanderud, K., Mbolatiana, H.Z.H., Vololomboahangy, M. N., Radimbison, M. A., Roger, E., Totland, O., \& Rajeriarison, C. (2010). Recovery of plant species richness and composition after slash-and-burn agriculture in a tropical rainforest in Madagascar. Biodiversity and Conservation 19 (1), 187-204. doi:10.1007/s10531-009-9714-3.

Kremen, C., Niles, J. O., Dalton, M. G., Daily, G. C., Ehrlich, P. R., Fay, J. P., Grewal, D., \& Guillery, R. P. (2000). Economic incentives for rain forest conservation across scales. Science 288 (5472), 1828-1832. doi:10.1126/science.288.5472.1828.

Kull, C. A. (1998). Leimavo revisited: Agrarian land-use change in the highlands of Madagascar. Professional Geographer 50 (2), 163-176. doi:10.1111/00330124.00112.

Kull, C. A. (2000). Deforestation, erosion, and fire: Degradation myths in the environmental history of Madagascar. Environment and History 6 (4), 423-450. doi:10.3197/096734000129342361.

Lambin, E. F., \& Meyfroidt, P. (2011). Global land use change, economic globalization, and the looming land scarcity. Proceedings of the National Academy of Sciences 108 (9), 3465-3472. doi:10.1073/pnas.1100480108. 
Lambin, E. F., Turner, B. L., Geist, H. J., Agbola, S. B., Angelsen, A., Bruce, J. W., Coomes, O. T., et al. (2001). The causes of land-use and land-cover change: Moving beyond the myths. Global Environmental Change 11 (4), 261-269. doi:10.1016/S09593780(01)00007-3.

Laney, R. M. (2002). Disaggregating induced intensification for land-change analysis: A case study from Madagascar. Annals of the Association of American Geographers 92 (4), 702-726. DOI: 10.1111/1467-8306.00312

Laurance, W.F., Sayer, J., \& Cassman, K. G. (2014). Agricultural expansion and its impacts on tropical nature. Trends in Ecology \& Evolution 29 (2), 107-16. doi:10.1016/j.tree.2013.12.001.

Locatelli, B. (2000). Pression démographique et construction du paysage rural des tropiques humides: l'exemple de Mananara (Madagascar). Montpellier: L'Ecole Nationale du Génie Rural, des Eaux et des Forêts Centre de Montpellier.

Magliocca, N. R., Rudel, T. K., Verburg, P. H., McConnell, W. J., Mertz, O., Gerstner, K., Heinimann, A., and Ellis, E. C. (2014). Synthesis in land change science: Methodological patterns, challenges, and guidelines. Regional Environmental Change 15 (2), 211-226. doi:10.1007/s10113-014-0626-8.

Malhi, Y., Gardner, T. A., Goldsmith, G. R., Silman, M. R., \& Zelazowski, P. (2014). Tropical forests in the Anthropocene. Annual Review of Environment and Resources 39 (1), 125-159. doi:10.1146/annurev-environ-030713-155141.

Mertz, O., Padoch, C., Fox, J., Cramb, R. A., Leisz, S. J., Lam, N. T., \& Vien, T. D. (2009). Swidden change in Southeast Asia: Understanding causes and consequences. Human Ecology 37 (May), 259-264. doi:10.1007/s10745-009-9245-2.

Messerli, P. (2004). Alternatives à la culture sur brûlis sur la falaise est de Madagascar: Stratégies en vue d'une gestion plus durable des terres. Vol. A17, African Studies Series. Bern, Switzerland: Geographica Bernensia.

Messerli, P., Bader, C., Hett, C., Epprecht, M., \& Heinimann, A. (2015). Towards a spatial understanding of trade-offs in sustainable development: A meso-scale analysis of the nexus between land use, poverty, and environment in the Lao PDR. PLOS ONE 10 (7): e0133418.

Messerli, P., Heinimann, A., \& Epprecht, M. (2009). Finding homogeneity in heterogeneityA new approach to quantifying landscape mosaics developed for the Lao PDR. Human Ecology 37 (3), 291-304. doi:10.1007/s10745-009-9238-1. 
Ministère de l'Environnement, des Forêts et du Tourisme (MEFT), United States Agency for International Development (USAID), and Conservation International (CI). (2009). Evolution de la couverture de forêts naturelles à Madagascar, 1990-2000-2005. Antananarivo, Madagascar: MEFT. Retrieved from http://www.bastamag.net/IMG/pdf/meft_usaid_ci_2009_etude_sur_la_de_forestation_ de_1990_a_2005_2_.pdf. Last accessed: 15.07.2015.

Myers, N., Mittermeier, R. A., Mittermeier, C. G., da Fonseca, G.A.B., \& Kent, J. (2000). Biodiversity hotspots for conservation priorities. Nature 403 (6772), 853-858. doi:10.1038/35002501.

Office National pour l'Environnement (ONE), Direction Générale des Forêts (DGF), FoibenTaosarintanin'i Madagasikara (FTM), Madagascar National Parks (MNP) and Conservation International (Cl). (2013). Evolution de la couverture de forêts naturelles à Madagascar 2005-2010. Antananarivo, Madagascar: ONE. Retrieved from http://www.pnae.mg/index.php/Autres/evolution-de-la-couverture-de-foretsnaturelles-a-madagascar-2005-2010.html. Last accessed: 20.05.2015.

Olofsson, P., Foody, G. M., Stehman, S. V., \& Woodcock, C. E. (2013). Making better use of accuracy data in land change studies: Estimating accuracy and area and quantifying uncertainty using stratified estimation. Remote Sensing of Environment 129 (February), 122-131. doi:10.1016/j.rse.2012.10.031.

Ostrom, E. (2007). A diagnostic approach for going beyond panaceas. Proceedings of the National Academy of Sciences 104 (39), 15181-15187. doi:10.1073/pnas.0702288104.

Pfund, J.-L., Watts, J.-D., Boissiere, M., Boucard, A., Bullock, R. M., Ekadinata, A., Dewi, S., et al. (2011). Understanding and Integrating local perceptions of trees and forests into incentives for sustainable landscape management. Environmental Management 48 (2), 334-349. doi:10.1007/s00267-011-9689-1.

Phalan, B., Onial, M., Balmford, A., \& Green, R. E. (2011). Reconciling food production and biodiversity conservation: Land sharing and land sparing compared. Science 333 (6047), 1289-1291. doi:10.1126/science.1208742.

Pontius, R. G., Jr., Shusas, E., \& McEachern, M. (2004). Detecting important categorical land changes while accounting for persistence. Agriculture Ecosystems \& Environment 101 (2-3), 251-268. doi:10.1016/j.agee.2003.09.008. 
Randriamalala, H., \& Liu, Z. (2010). Rosewood of Madagascar: Between democracy and conservation. Madagascar Conserv. \& Dev. 5 (1), 11-22.

Reenberg, A. (2009). Land system science: Handling complex series of natural and socioeconomic processes. Journal of Land Use Science 4 (1-2), 1-4. doi:10.1080/17474230802645618.

Rindfuss, R. R., Entwisle, B., Walsh, S. J., Mena, C. F., Erlien, C. M., \& Gray, C. L. (2007). Frontier land use change: Synthesis, challenges, and next steps. Annals of the Association of American Geographers 97 (4), 739-754. doi:10.1111/j.14678306.2007.00580.x.

Schmidt-Vogt, D., Leisz, S. J., Mertz, O., Heinimann, A., Thiha, T., Messerli, P., Epprecht, M., et al. (2009). An assessment of trends in the extent of swidden in Southeast Asia. Human Ecology 37 (3), 269-280. doi:10.1007/s10745-009-9239-0.

Schuurman, D., \& Lowry, P. P. (2009). The Madagascar rosewood massacre. Madagascar Conserv. \& Dev. 4 (2), 98-102. doi: 10.4314/mcd.v4i2.48649.

Sirén, A. H., \& Brondizio, E. S. (2009). Detecting subtle land use change in tropical forests. Applied Geography 29 (2), 201-211. doi:10.1016/j.apgeog.2008.08.006.

Styger, E., Rakotondramasy, H. M., Pfeffer, M. J., Fernandes, E.C.M., \& Bates, D. M. (2007). Influence of slash-and-burn farming practices on fallow succession and land degradation in the rainforest region of Madagascar. Agriculture, Ecosystems \& Environment 119 (3-4), 257-269. doi:10.1016/j.agee.2006.07.012.

Turner, B. L., Lambin, E. F., \& Reenberg, A. (2007). The emergence of land change science for global environmental change and sustainability. Proceedings of the National Academy of Sciences 104 (52), 20666-20671. doi:10.1073/pnas.0704119104.

Urech, Z. L., Rabenilalana, M., Sorg, J.-P., \& Felber, H. R. (2011). Traditional use of forest fragments in Manompana, Madagascar. In C.J.P. Colfer and J.-L. Pfund (Eds.), Collaborative governance of tropical landscapes (pp. 131-155). London: Earthscan.

van Vliet, N., Mertz, O., Heinimann, A., Langanke, T., Pascual, U., Schmook, B., Adams, C., et al. (2012). Trends, drivers and impacts of changes in swidden cultivation in tropical forest-agriculture frontiers: A global assessment. Global Environmental Change 22 (2), 418-429. doi:10.1016/j.gloenvcha.2011.10.009. 
Verburg, P. H., van de Steeg, J., Veldkamp, A., \& Willemen, L. (2009). From land cover change to land function dynamics: A major challenge to improve land characterization. Journal of Environmental Management 90 (3), 1327-1335. doi:10.1016/j.jenvman.2008.08.005.

World Bank. (2013). Madagascar country environmental analysis (CEA): Taking stock and moving forward. Washington, DC: World Bank. Retrieved from: http://documents.worldbank.org/curated/en/2013/05/17759163/madagascar-countryenvironmental-analysis-cea-taking-stock-moving-forward. Last accessed: 15.12.2015.

World Bank. (2015). World databank. Retrieved from http://databank.worldbank.org/data/reports.aspx?source=world-developmentindicators. Last accessed: 03.07.2015.

World Wildlife Fund. (2007). Madagascar forests. Forest area key facts \& carbon emissions from deforestation. Washington, DC: WWF. Retrieved from http://d2ouvy59p0dg6k.cloudfront.net/downloads/madagascar_forest_cc_final_12nov 07.pdf.

Zaehringer, J. G., Eckert, S., \& Messerli, P. (2015). Revealing regional deforestation dynamics in north-eastern Madagascar-Insights from multi-temporal land cover change analysis. Land 4 (2), 454-474. doi:10.3390/land4020454. 


\section{Graphical Abstract}

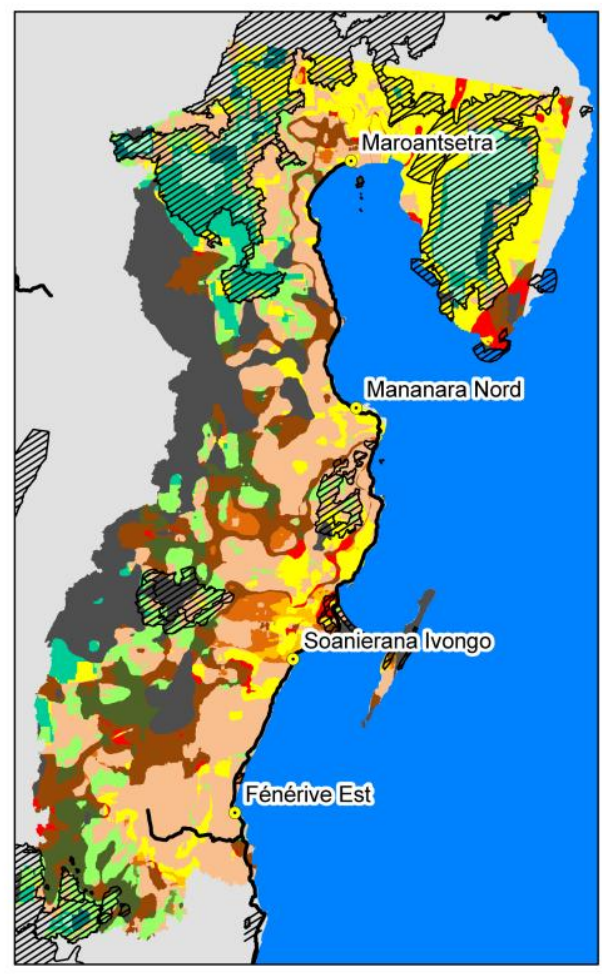

$1: 1,750,000$
Major towns

Major roads

\#IIA Protected areas

Landscape change trajectory

Staple crop intensification; loss of tree cover

Staple crop intensification; increase in tree cover

Staple crop intensification; no change in tree cover

Staple crop extensification; loss of tree cover

Staple crop extensification; increase in tree cover

Staple crop extensification; no change in tree cover No change in staple crop intensity; loss of tree cover No change in staple crop intensity; increase in tree cover

Abandonment of staple crop cultivation

New staple crop cultivation

No staple crop cultivation

No change

No data

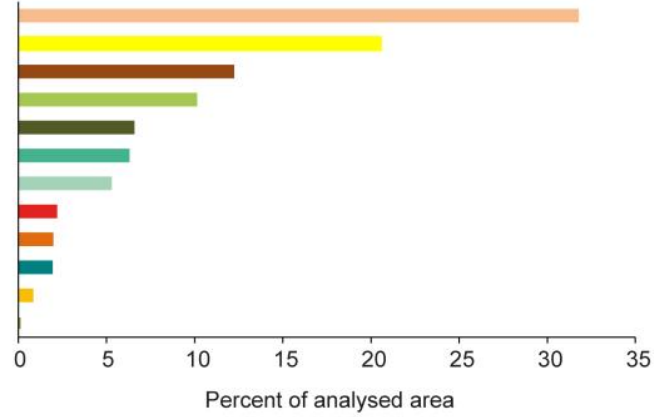

$\begin{array}{llll}25 & 50 & 75 & 100\end{array}$ 